\title{
Dermatitis Due to Paederus Colombinus: Report of an Epidemic Outbreak of 68 Cases in the Province of Darien, Panama
}

Lorenzo Cáceres ${ }^{1}$, Jose A. Suarez ${ }^{2}$, Carmela Jackman ${ }^{3}$, Amanda Galbster ${ }^{2}$, Roberto Miranda ${ }^{1}$, Ingrid Murgas ${ }^{1}$, Juan Pascale ${ }^{2}$, Nestor Sosa ${ }^{2}$, Alfonso J. Rodriguez-Morales ${ }^{4}$

1. Entomology Section, Instituto Conmemorativo Gorgas De Estudios De La Salud, Panama City, Panama 2. Clinical Research Department, Instituto Conmemorativo Gorgas De Estudios De La Salud, Panama City, Panama 3. Epidemiology, Ministerio De Salud (Minsa), Darién, Panama 4. Epidemiology and Public Health, Universidad Tecnológica De Pereira, Pereira, COL

$\square$ Corresponding author: Alfonso J. Rodriguez-Morales, arodriguezm@utp.edu.co Disclosures can be found in Additional Information at the end of the article

\section{Abstract}

\section{Introduction}

Contact dermatitis due to Paederus is a particular form of accident by animal contact. It is characterized by the sudden onset of erythematous and vesicular lesions with burning sensation on exposed areas of the body. The aim of this study was to describe the epidemiological and clinical findings of an outbreak of Paederus dermatitis in Panama.

\section{Methods}

Clinical and epidemiological findings of an outbreak of contact dermatitis caused by Paederus sp. in the province of Darien in eastern Panama is reported. After reviewing the clinical records, a clinical-epidemiological questionnaire was developed and used in 20 communities where reported cases were found. We captured and collected the specimens for species characterization for three consecutive days using three different methods of capture.

\section{Results}

During May-July, 2014, 68 cases of Paederus irritant contact dermatitis occurred in 20 communities of the Darien. Fifty-three percent were females. The age group of zero to five years had the highest number of cases, 15 (22\%). The most common clinical presentation was the classical linear dermatitis (58\%); $42 \%$ of the subjects had mirror image lesions, multiple vesicular-pustular lesions, and crust lesions. Symptoms were most commonly reported as a burning sensation (65\%), followed by pruritus in 60\%, pain (25\%), and fever (nine percent). A total of 81 specimens of Paederus were collected, 68\% in peridomiciliary areas.

\section{Received 04/03/2017}

Review began 04/06/2017

Review ended 04/06/2017

Published 04/12/2017

\section{(c) Copyright 2017}

Cáceres et al. This is an open access article distributed under the terms of the Creative Commons Attribution License CC-BY 3.0., which permits unrestricted use, distribution, and reproduction in any medium, provided the original author and source are credited.

\section{Conclusions}

This Paederus sp. dermatitis report represents one of the largest outbreak described in Latin America and the diagnosis could be confused with others skin diseases like pyodermitis or other contact dermatitis.

Categories: Dermatology, Infectious Disease, Public Health

Keywords: dermatitis linearis, paederus, arthropod, vesicating, dermatitis, panama 


\section{Introduction}

Contact dermatitis due to Paederus sp. is a way of accident by animal contact. It is characterized by the sudden onset of erythematous and vesicular lesions with burning sensation on exposed areas of the body. The toxin, paederina, from the endolymph of insects of Paederus genus causes the disease. Diagnosis is supported by characteristic lineal or mirror lesion patterns and the sudden onset a burning sensation, accompanied by the epidemiological context of the patient [1-2].

The Paederus genus has approximately 622 species, 30 of which have been shown to cause lineal dermatitis or to contain the paederin toxic agent [3-5]. Paederus belongs to the Staphyllinadae family, Paederinae subfamily, and is widely distributed throughout the world, except in Antarctica [5].

Accidental contact with the insects causes lesions in humans; however, authors in the past believed erroneously that Paederus sp. caused these lesions due to biting or stinging. Once the beetle comes in contact with the individual, they will try to brush the insect off, thereby disseminating the paederina, producing contact dermatitis to varying degrees. The severity of the lesion varies by anatomic area. Eye damage such as conjunctivitis and keratitis may occur [ 4 , 6-7].

It is important to note that the clinical diagnosis is eminently epidemiological. In doubtful cases, pathologic examination can be performed to confirm diagnosis; however, findings such as spongiosis and exocytosis of neutrophils, intraepidermal vesicles and epidermal necrosis with dermal edema with interstitial inflammatory infiltrate and perivascular without immunocomplex deposits, should be correlated with the findings of the medical history of patients $[6,8]$.

Conventional management of contact dermatitis is recommended: removal of irritant, wash with soap and water, and application of moist bandages. Antibiotics are only used if a secondary infection is present. Oral antihistamines and topical corticosteroids are useful in relieving symptoms.

Most outbreaks of Paederus dermatitis have been reported in Asia. In the Americas, only 10 reports are available, the last in 2013 and only one of them is from Panama in 1982.

\section{Materials And Methods}

The aim of this study is to perform a clinical and epidemiological description of an outbreak of contact dermatitis caused by Paederus sp. in the province of Darien in eastern Panama by analyzing the possible causes of this outbreak and to make suggestions for future prevention and control.

In July 2014, an unusually high number of dermatitis cases were observed. Local interpretation was of impetigo or pyoderma, characterized by poor response to antibiotic treatment. This led the regional epidemiologist from the Ministry of Health to investigate the cases.

The first 10-suspected cases were investigated. Evaluation of clinical and epidemiological findings was undertaken. Case definition of the dermatitis lesions was developed for the suspected outbreak of lineal dermatitis due to Paederus sp.

Case definition: all skin lesions, characterized as flat and linear with surrounding erythema; one of the following central characteristics: lesion like a burn with crusty appearance or a 


\section{Cureus}

vesicular lesion with or without history or contact with insect in patients that live in or have visited Darien since May 2014.

Based on the case definition, a retrospective study was performed during the previous two months since the first cases presented. This ensured that individuals who were most likely to be involved in the outbreak were included in this study. The diagnosis at the time of hospital or health center discharge as well as outpatient records to health centers in the towns of, Metetí, Platanilla, Santa Fe were used.

After reviewing the clinical records, a clinical-epidemiological questionnaire was developed and used in 20 communities where reported cases were found. This questionnaire included sociodemographic variables (sex, age, among others), date and place of occurrence, as well clinical manifestations related to the lesions (anatomical location, symptoms, risk factors).

An epidemiological field study was conducted in the endemic area of Paederus sp. This included specimen capture and collection for species characterization. This study was undertaken in districts that reported clinical cases (Rio Congo Arriba, Agua Fria, Santa Fe, Meteti, Yaviza). Three of these districts were chosen (Metetí, Rio Congo Arriba, and Agua Fria) for entomological field search (Figure 1).

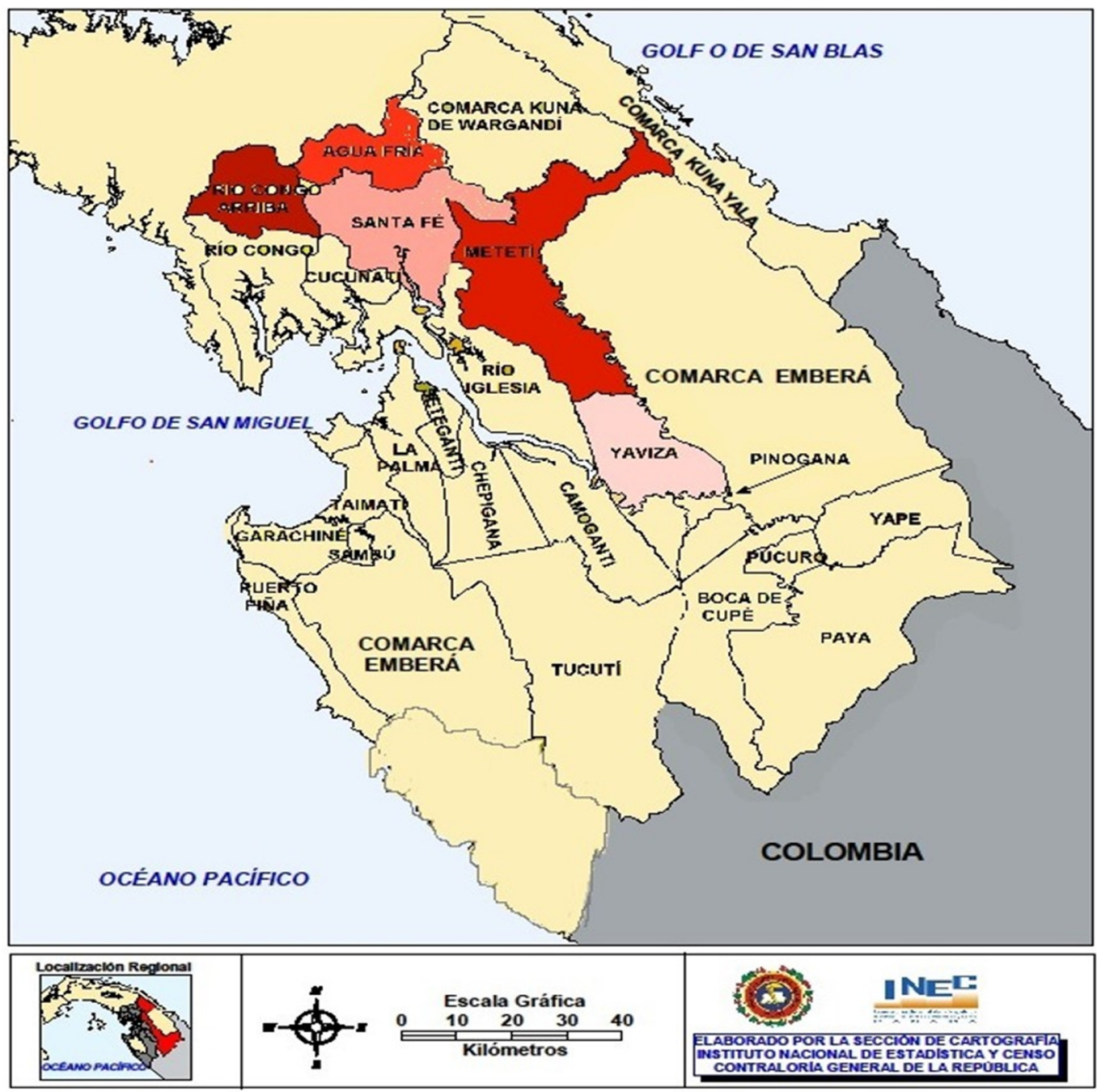

FIGURE 1: Study area, Darien province, Panama 


\section{Cureus}

Specimens were collected for three consecutive days using three different methods of capture. During the daytime hours, active searching and capture were undertaken using entomological forceps within and around households and selected homes. Nighttime capture using ultraviolet light traps placed around houses was also used. Community members were trained to capture the insects in locations where reported cases were found using containers that were supplied by the study team. All biological material was collected and transferred to previously coded vials containing 70\% ethanol and transported to the Department of Medical Entomology at the Gorgas Memorial Institute for identification and classification.

This study has been reviewed and approved by the IRB of Instituto Conmemorativo Gorgas de Estudios de la Salud, Panama City, Panama. In addition to this, informed consent was obtained from the patients, also including that they authorized photographs to be taken and be used in this article.

\section{Results}

During May to July 2014, a total of 68 cases of Paederus irritant contact dermatitis were reported in 20 communities of the Darien Province in Panama (Figure 2).

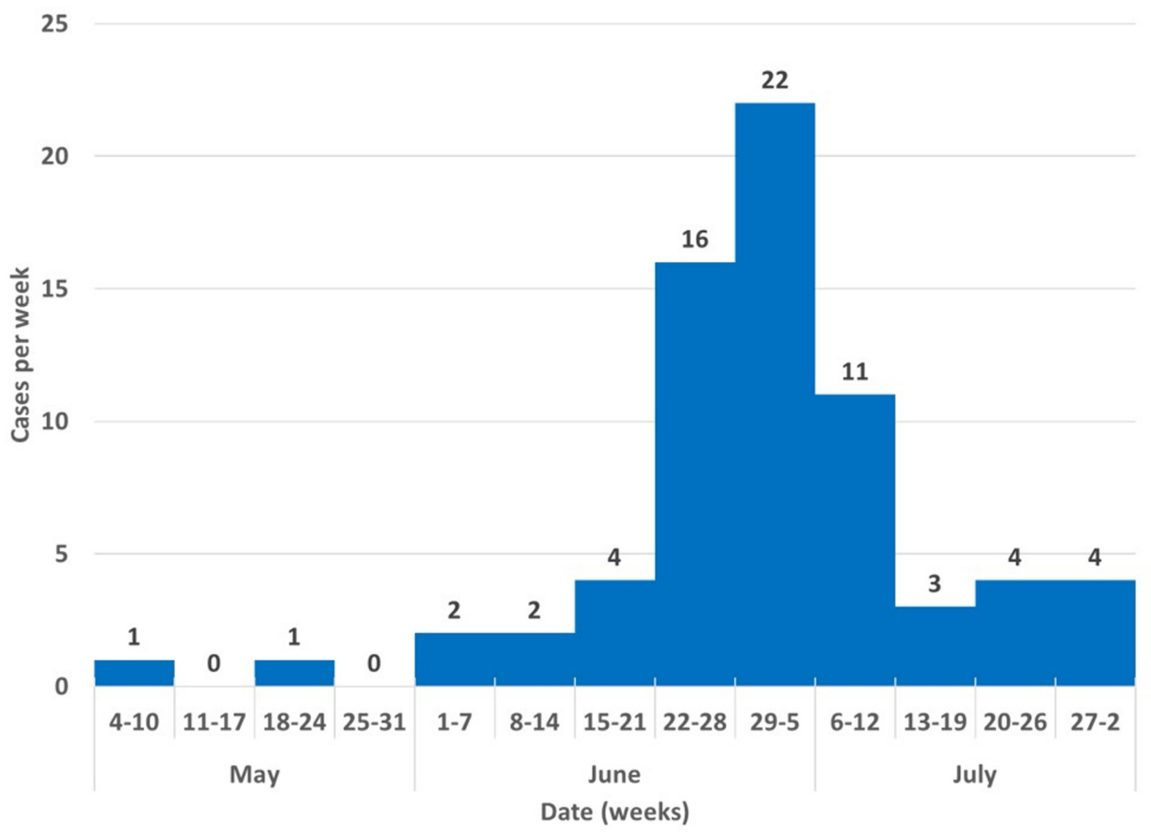

FIGURE 2: Distribution of Paederus dermatitis cases in Darien, Panama, by epidemiological weeks, May 4-August 2, 2014

These cases were reported by three different health centers (Platanillas, Santa Fe, and Metetí). The diagnosis was suspected based on the clinical appearance of the lesions.

Fifty-three percent of those affected were females. The age group of 0 to 5 years had the highest absolute number of cases, 15 (22.1\%); the highest incidence rate was found in 35-39 year olds, 1.2 per 10,000 (Table 1 ). 


\section{Cureus}

\begin{tabular}{|c|c|c|c|c|}
\hline Variable & $\mathbf{N}$ & $\%$ & $95 \% \mathrm{Cl}$ & Attack rates \\
\hline \multicolumn{5}{|l|}{ Sex } \\
\hline Male & 32 & $47.05 \%$ & $35.09-59.45$ & 0.21 \\
\hline Female & 36 & $52.94 \%$ & $40.55-64.91$ & 0.29 \\
\hline \multicolumn{5}{|l|}{ Age (y-old) } \\
\hline $0-4.99$ & 15 & $22.06 \%$ & $12.90-33.16$ & 1.08 \\
\hline $5-9.99$ & 7 & $10.29 \%$ & $4.24-20.07$ & 0.51 \\
\hline $10-14.99$ & 6 & $8.82 \%$ & $3.31-18.22$ & 0.39 \\
\hline $15-19.99$ & 2 & $2.94 \%$ & $0.36-10.22$ & 0.12 \\
\hline $20-24.99$ & 10 & $14 . / 1 \%$ & $1.28-25.39$ & 0.68 \\
\hline $25-29.99$ & 6 & $8.82 \%$ & $3.31-18.22$ & 0.54 \\
\hline $30-34.99$ & 3 & $4.41 \%$ & $0.92-12.36$ & 0.42 \\
\hline $35-39.99$ & 7 & $10.29 \%$ & 4.2420 .07 & 1.22 \\
\hline $40-44.99$ & 3 & $4.41 \%$ & $0.92-12.36$ & 0.50 \\
\hline $45-49.99$ & 1 & $1.47 \%$ & 0.04-7.92 & 0.21 \\
\hline $50-54.99$ & 3 & $4.41 \%$ & $0.92-12.36$ & 0.72 \\
\hline $55-59.99$ & 2 & $2.94 \%$ & $0.36-10.22$ & 0.58 \\
\hline 60 and older & 3 & $4.41 \%$ & $0.92-12.36$ & 1.03 \\
\hline
\end{tabular}

\section{TABLE 1: Distribution by age group and attack rate of contact dermatitis from}

\section{Paederus, Darien, Panama, 2014}

$95 \% \mathrm{Cl}=95 \%$ confidence interval; $y$-old = years old.

A structured interview ordered by the Ministry of Health was applied to 43 of the 68 subjects to better characterize this outbreak as part of an epidemiological investigation. Of those interviewed, 51\% were females; the median age was 18 years.

The most common clinical presentation from 43 of the 68 subjects interviewed was the classical linear dermatitis (58.1\%). $41.9 \%$ of the subjects had mirror image lesions, multiple vesicularpustular lesions, and crust lesions (Figure 3). 


\section{Cureus}

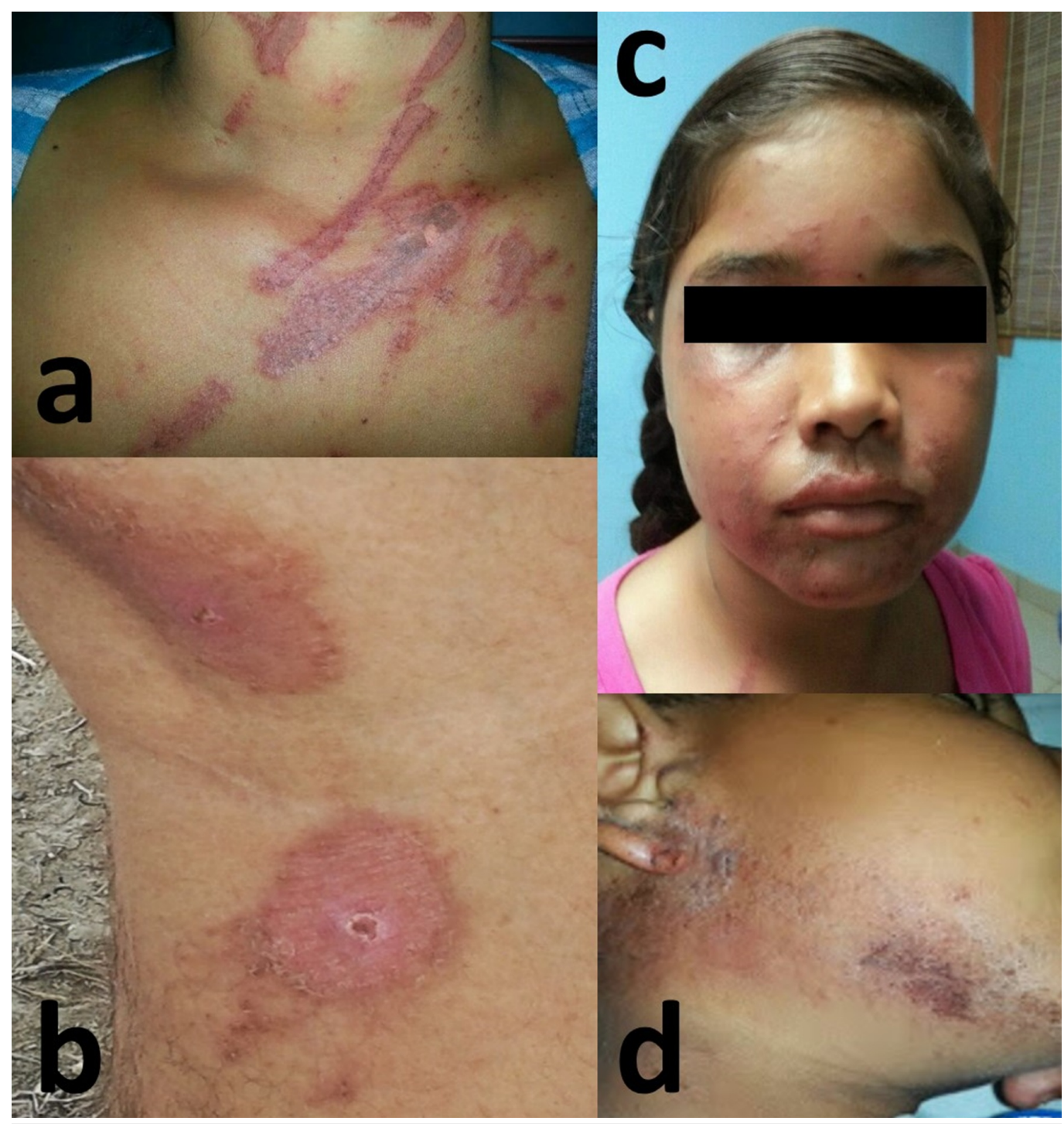

FIGURE 3: Cutaneous manifestations of dermatitis from Paederus observed during the outbreak. (a) Vesicular linear dermatitis. (b) Mirror lesion. (c) Multiple vesicular-pustular lesions and crust lesions in the face. (d) Multiple vesicularpustular lesions and crust lesions in the periauricular and mandibular areas

In 17 of 43 subjects, the lesions were in the face, making this the most common anatomical site (39.53\%) (Figure 3C). The anatomical site next most affected was arms and lower extremities, this occurred in $27.9 \%$ of the patients.

Symptoms were most commonly reported as a burning sensation in $65.1 \%$ (28/43), followed by pruritus in $60.4 \%$ (26/43); 25\% reported pain. Only four patients $(9.3 \%)$ reported fever.

All individuals interviewed lived in rural communities. The majority, 73\% (30/41), did not have metallic screens on the doors or windows. Almost all, 95\% (41/43), reported the use of white lights inside and outside of the houses. Ornamental plants and/or fruit trees surrounded most of these houses. 


\section{Cureus}

Regarding the entomological captures, with the three methods used during the three days of fieldwork, we collected 81 specimens of Paederus sp. (Figure 4).

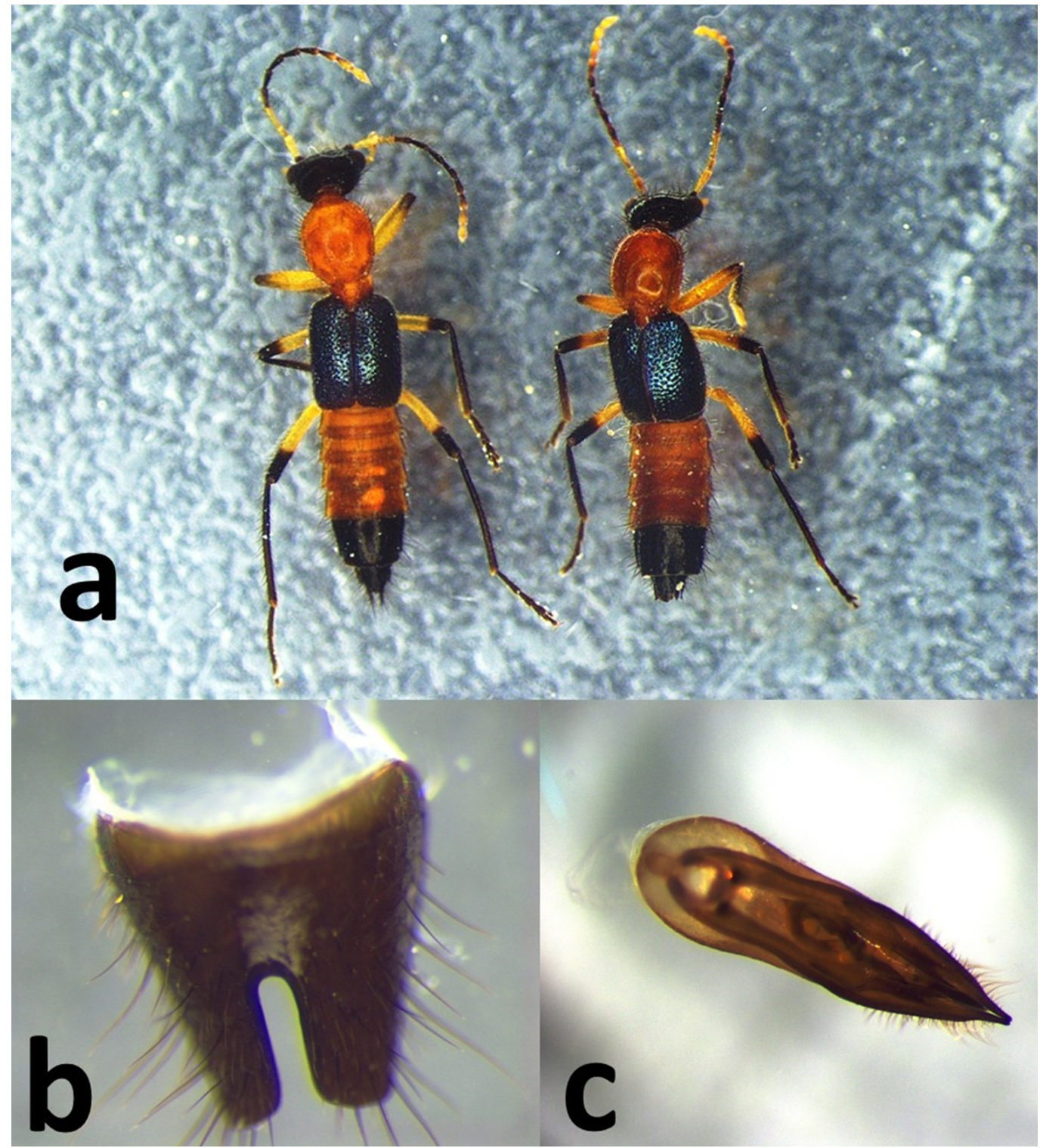

FIGURE 4: Entomological findings and morphological characteristics for genus identification. (a) Male and female of Paederus captured in Darien. (b) labrum. (c) reproductive male structures.

The greatest number, 55 (68.0\%), of Paederus sp. were captured in the areas around houses. More than half, 43 (53.1\%), of the samples were found through active searching methods and the remainder was through community participation. Nighttime collection with ultraviolet light traps was not able to capture any Paederus sp. specimens.

It is important to note that captures were made in four of the five townships where cases of dermatitis were evaluated (Rio Congo, Meteti, Santa Fe, Agua Fria). In the district of Yaviza there were no captures (Figure 5). 


\section{Cureus}

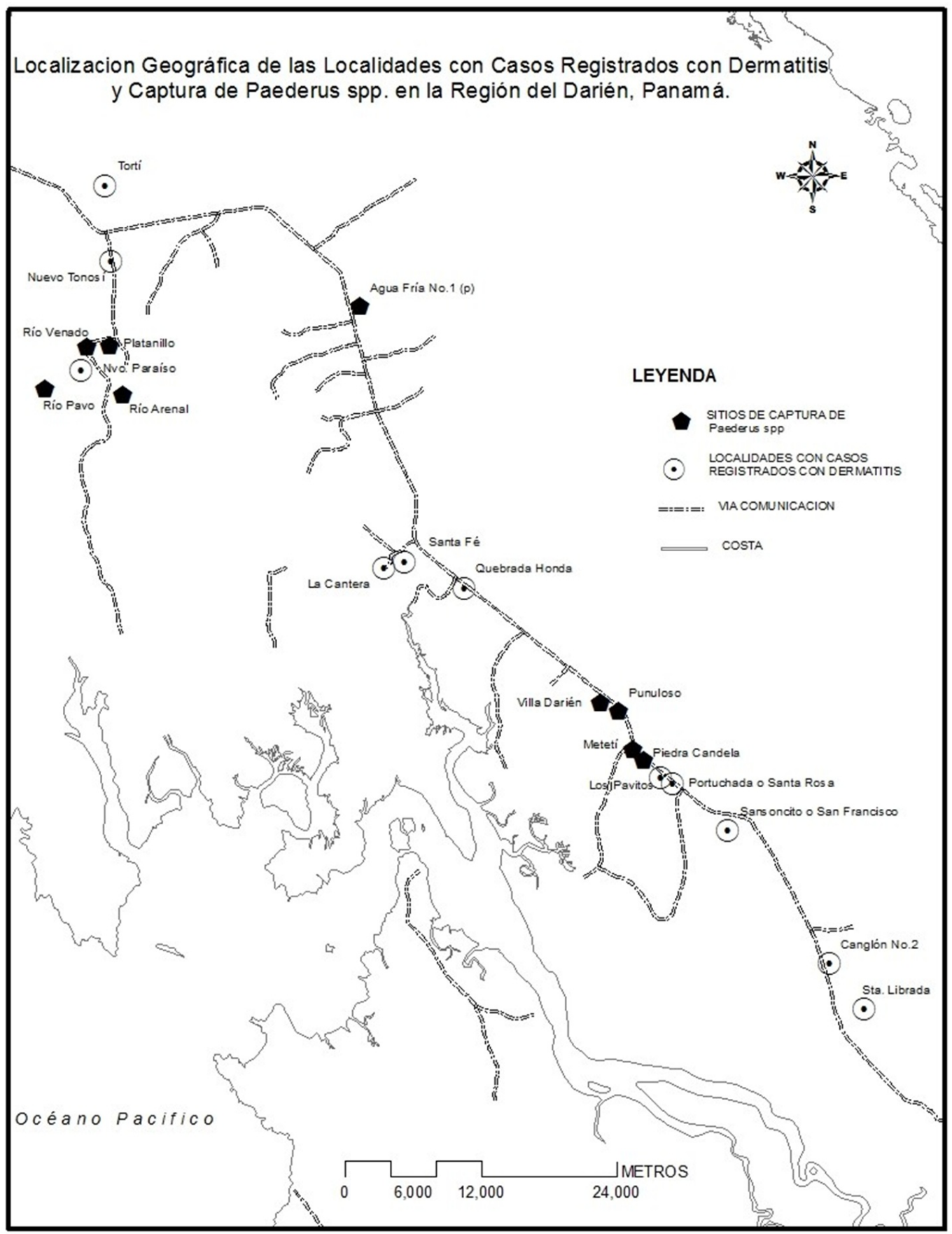

FIGURE 5: Localization of places with cases of Paederus dermatitis and entomological captures, Darien, Panama

The greatest number, 46 (57.0\%), of Paederus sp. insects were captured in Río Congo Arriba, followed by Metetí with 31 (38.3\%) of the captures, Santa Fe and Agua Fria, each with two (2.5\%) captures (Table 2) (Figure 5). 


\section{Cureus}

\begin{tabular}{|lllllll|}
\hline Corregiment & Localization & N & $\%$, capture & Place & Type of collection \\
\hline Río Congo Arriba & Platanillas & 8 & 9.9 & Peridomestic & At community \\
Río Congo Arriba & Río Venado & 5 & 6.2 & Intradomicilio & Active search \\
Río Congo Arriba & Río Arenal & 28 & 35 & Peridomestic & Active search \\
Río Congo Arriba & Agua Fría & 5 & 6.2 & Peridomestic & At community \\
Meteti & Punuloso & 9 & 11.1 & Intradomicilio & At community \\
Meteti & Meteti & 8 & 9.9 & Intradomicilio & At community \\
Meteti & Piedra Candela & 6 & 7.4 & Peridomestic & At community \\
Meteti & Villa Darién & 8 & 9.9 & Peridomestic & Active search \\
Santa Fe & Santa Fe & 2 & 2.5 & Intradomicilio & At community \\
Agua Fría & Agua Fría No. 1 & 2 & 2.5 & Intradomicilio & Active search \\
\hline
\end{tabular}

TABLE 2: Captures of Paederus spp. (Coleoptera: Staphylinidae), in places were dermatitis cases occurred, Darien, Panama

\section{Discussion}

The Paederus sp. releases a toxic hemolymph (Paederina) which generally occurs when the beetle is brushed or rubbed on the skin or when there is accidental contact with the skin. An inflammatory reaction, known as contact dermatitis from Paederus sp. or lineal vesicular dermatitis occurs [9-10]. In Panama, the species $P$. signaticornis and $P$. columbinus have been reported to cause severe dermatitis. In Central America, the species P. laetus, $P$. ardus, $P$. luridiventris, and P. salivini exist, however only P. laetus has been shown to cause cases of dermatitis in Guatemala [11-12].

The outbreak of dermatitis in the Darien region is characterized by an unusual increase in the population of Paederus sp. as well as several cases of dermatitis in villages that are located adjacent to the Pan American highway. Most the cases ranged along $110 \mathrm{~km}$ of highway from the western extreme at the town of Tortí, located at the eastern part of the province of Panama, to the most eastern town of Yaviza in the province of Darien. The increase in the population of the Paederus sp. was found with an invasion of these beetles in the houses. The insects most likely were attracted by the light which brought them into the rooms where they met humans. The patient reports show that dermatitis by Paederus sp. occurred mostly at night. This species of beetle is characterized by having mostly nocturnal activity and are attracted by artificial light [11-12].

In Pakistan, a Paederus sp. dermatitis outbreak showed most of the affected persons worked at night near artificial lights; the beetles were collected directly below light sources [13]. This outbreak involved 191 cases [13]. It is common for the insects to become active an hour after sunset [14]. The species showed variable behavior, which indicates their attraction to ultraviolet and white light; they are relatively insensitive to orange and yellow light [15]. However, in an outbreak in Tanzania, ultraviolet light was not found to attract the insects but 
the incandescent yellow light did [16].

Collection sites for Paederus sp. in this study were natural ecological areas, including savannah or grasslands with varying amounts of surrounding shrubs and secondary forests that were invaded by anthropogenic activity. Houses were mostly located near grasslands and secondary forests. Dwellings had favorable conditions in regards to basic health services, such as sewage disposal, water, electricity and general hygiene and sanitation. One of the social and environmental aspects, which could eventually contribute to Paederus sp. incidents in the region, is that although almost all homes maintain good hygiene, many people keep the windows open at night without the use of protective screens. This may constitute an important factor for contact with Paederus sp. [4].

In Malaysia, $P$. fuscipes was found inside homes, mainly in bedrooms, hallways, in bathrooms, and on walls [12]. Those who live in homes under impoverished conditions may be two times more likely to become ill than the rest of the community. That said, in our investigation, housing conditions were not a differentiating factor [17-18].

The unusual increase in the Paederus sp. population and the increased dermatitis cases have been shown to occur during the rainy season [19-20]. Ecological changes and climatic variations, such as El Niño, have also led to the appearance of unusual outbreaks of dermatitis caused by some species of these insects, which increase year after year in some regions worldwide [21-22]. Global warming can also lead to increased incidence of Paederus sp. since higher temperatures may influence the ecological dynamics of some insect species [23].

The increases in Paederus sp. populations and the dermatitis case reports in this outbreak in the province of Darien could be due to climatic changes related to the onset of the rainy season; unfortunately, due to the limitation of current study, such variables were not available during the outbreak period in order to correlate them with the case incidence. Heavy rainfall and consequently the increase of vegetation in deforested areas and along with the change in temperature and humidity cause an alteration in the natural habitat of these insects. This leads to the migration and proliferation of these insects to more urbanized areas, especially where there is artificial light. The elimination of natural predators has created an ecological imbalance in the habitat of Paederus sp. [21-22].

Thermal fogs and residual spraying with pyrethroid insecticides inside and outside dwellings can be used to control insects that invade and remain in houses. In an outbreak of dermatitis Paederus sp. in Malaysia, the use of thermal fog, residual spraying, and adhesive material was placed near the light sources to control the insects [24]. Also, other mechanisms in order to prevent the contact with the Paederus - such as not to crush these insects, learn to identify, close window or doors - are important to be instructed in the population.

Epidemic dermatitis by Paederus sp. described in South America is related to climatic phenomenon like the El Niño. These outbreaks affected urbanized areas, like what we describe in the Darien outbreak. In an outbreak in Peru [13], adjacent townships were involved, like the outbreak we studied in Darien.

From a clinical point of view, there are two main families of beetles that could be confused during identification. The family meloidea has two genuses, which are Lytta and Epicauta; these produce a powerful irritant known as cantharidin, which is observed in bullous lesions of skin and mucosal tissue. Insects of the family Staphylinidae, which has the Paederus genus, cause the classical lineal dermatitis described in this study. The amide discharge has a vesicant greater than cantharidin and causes intense erythema vesicles and scabs in humans [25-30]. 
Our patients had classical dermatitis lesions from Paederus sp., as described in the literature [4]. We observed many cases with facial lesions and lesions on exposed areas. Burning and itching were reported in our group as in other reported cases and outbreaks described in the literature. Systemic symptomatic fever was only reported in a low percentage of cases [26-27].

\section{Conclusions}

This Paederus sp. dermatitis report represents one of the largest outbreak described in Latin America and the diagnosis could be confused with other skin diseases like pyodermitis or other contact dermatitis. Then, dermatitis linearis differential diagnosis should be considered in cases with these findings, specially in Panama and other countries of the region.

\section{Additional Information}

\section{Disclosures}

Human subjects: Consent was obtained by all participants in this study. Study approved by the IRB of Instituto Conmemorativo Gorgas de Estudios de la Salud, Panama City, Panama. Animal subjects: All authors have confirmed that this study did not involve animal subjects or tissue. Conflicts of interest: In compliance with the ICMJE uniform disclosure form, all authors declare the following: Payment/services info: All authors have declared that no financial support was received from any organization for the submitted work. Financial relationships: All authors have declared that they have no financial relationships at present or within the previous three years with any organizations that might have an interest in the submitted work. Other relationships: All authors have declared that there are no other relationships or activities that could appear to have influenced the submitted work.

\section{Acknowledgements}

This study was previously presented in part at the IDWeek 2015, San Diego, California, USA, October 7-11, 2015, as Poster (No. 1641).

\section{References}

1. Vanhecke C, Malvy D, Guevart E, et al.: Dermatite à Paederus: étude rétrospective de 74 cas survenus en 2008 à Conakry, Guinée. [Article in French]. Ann Dermatol Vénéréol. 2010, 137:189-193. 10.1016/j.annder.2010.02.003

2. Gnanaraj P, Venugopal V, Kuzhal Mozhi M, et al.: An outbreak of Paederus dermatitis in a suburban hospital in South India: a report of 123 cases and review of literature. J Am Acad Dermatol. 2007, 57:297-300. 10.1016/j.jaad.2006.10.982

3. Kanamitsu K, Frank JH: Paederus, sensu lato (Coleoptera: Staphylinidae): natural history and medical importance. J Med Entomol. 1987, 24:155-191. 10.1093/jmedent/24.2.155

4. Cressey BD, Paniz-Mondolfi AE, Rodríguez-Morales AJ, et al.: Dermatitis linearis: vesicating dermatosis caused by Paederus species (coleoptera: staphylinidae). Case series and review. Wilderness Environ Med. 2013, 24:124-131. 10.1016/j.wem.2012.11.005

5. Gibbs LM: Beware of the beetle: a case report of severe vesicating dermatitis . Mil Med. 2015, 180:e1293-e1295. 10.7205/MILMED-D-15-00350

6. Singh G, Yousuf Ali S: Paederus dermatitis. Indian J Dermatol Venereol Leprol. 2007, 73:1315. 10.4103/0378-6323.30644

7. Verma S, Gupta S.: Ocular manifestations due to econda (Paederus sabaeus). Med J Armed Forces India. 2012, 68:245-248. 10.1016/j.mjafi.2011.11.006

8. Huang C, Liu Y, Yang J, et al.: An outbreak of 268 cases of Paederus dermatitis in a toybuilding factory in central China. Int J Dermatol. 2009, 48:128-131. 10.1111/j.13654632.2009.03876.x

9. Gelmetti C, Grimalt R: Paederus dermatitis: an easy diagnosable but misdiagnosed eruption. Eur J Pediatr. 1993, 152:6-8. 10.1007/BF02072506 
10. Bazrafkan S, Vatandoost H, Heydari A, et al.: Discrimination of Paederus fuscipes and Paederus littoralis by mtDNA-COI PCR-RFLP. J Arthropod Borne Dis. 2016, 4:454-461.

11. Mendez E, Iglesias CA: Epidemic outbreak of dermatitis caused by Paederus signaticornis Sharp (Coleoptera: staphylinidae) observed in José Domingo de Obaldía Hospital, David, Panama. Rev Med Panama. 1982, 7:53-58.

12. Heo CC, Latif B, Hafiz WM, et al.: Dermatitis caused by Paederus fuscipes Curtis, 1840 (Coleoptera: Staphilinidae) in student hostels in Selangor, Malaysia. Southeast Asian J Trop Med Public Health. 2013, 44:197-205.

13. Dursteler BB, Nyquist RA: Outbreak of rove beetle (Staphylinid) pustular contact dermatitis in Pakistan among deployed US personnel. Mil Med. 2004, 169:57-60.

14. Davidson SA, Norton SA, Carder MC, et al.: Outbreak of dermatitis linearis caused by Paederus ilsae and Paederus iliensis (Coleoptera: Staphylinidae) at a military base in Iraq. US Army Med Dep J. 2009, 6-15.

15. Hudson JE, Young DG: New records of phlebotomines, leishmaniasis and mosquitoes from Suriname. Trans R Soc Trop Med Hyg. 1985, 79:418-419.

16. Narasimhalu CR, Murali A, Kannan R, et al.: Blister beetle dermatitis. J Indian Med Assoc. 2010, 108:781-782.

17. Mokhtar N, Singh R, Ghazali W: Paederus dermatitis amongst medical students in USM, Kelantan. Med J Malaysia. 1993, 48:403-406.

18. Kerdel-Vegas F, Goihman-Yahr M: Paederus dermatitis. Arch Dermatol. 1966, 94:175-185. 10.1001/archderm.1966.01600260067008

19. Alva-Dávalos V, Laguna-Torres VA, Huamán A, et al.: Dermatite epidêmica por Paederus irritans em Piura, Perú, 1999, relacionada ao fenômeno El Niño. Rev Soc Bras Med Trop. 2002, 35:23-28. 10.1590/S0037-86822002000100005

20. Qadir SN, Raza N, Rahman SB: Paederus dermatitis in Sierra Leone . Dermatol Online J. 2006, 12:9.

21. Senel E, Sahin C: A warmer world means more beetles and more dermatitis . Indian J Occ Env Med. 2011, 15:47. 10.4103/0019-5278.82993

22. Rahmah E, Norjaiza MJ: An outbreak of Paederus dermatitis in a primary school . Malays J Pathol. 2008, 30:53-56.

23. Bravo F, Sanchez MR: New and re-emerging cutaneous infectious diseases in Latin America and other geographic areas. Dermatol Clin. 2003, 21:655-668.

24. Haddad V Jr, Cardoso JL, Lupi O, et al.: Tropical dermatology: venomous arthropods and human skin: Part I. Insecta. J Am Acad Dermatol. 2012, 67:331.e1-e14. 10.1016/j.jaad.2012.04.048

25. Lefkowitz RY, Ridge GE: Paederus dermatitis in a seafarer diagnosed via telemedicine collaboration. J Travel Med. 2016, 23 :taw017. 10.1093/jtm/taw017

26. Stanimirović A, Skerlev M, Culav-Košćak I, et al.: Paederus dermatitis featuring chronic contact dermatitis. Dermatitis. 2013, 24:249-251. 10.1097/DER.0b013e3182948234

27. Uzunoğlu E, Oguz ID, Kir B, et al.: Clinical and epidemiological features of Paederus dermatitis among nut farm workers in Turkey. Am J Trop Med Hyg. 2017, 96:483-487. 10.4269/ajtmh.160582

28. Kollipara R, Reisz G, Reisz C: Control of the rove beetle in rapidly deployed Ebola treatment units (ETUs) is necessary for worker safety. JAAD Case Rep. 2015, 1:406-407.

10.1016/j.jdcr.2015.10.002

29. Suwannahitatorn P, Jatapai A, Rangsin R: An outbreak of Paederus dermatitis in Thai military personnel. J Med Assoc Thai. 2014, 97:S96-S100.

30. Lima DC, Costa AA, Silva FS: Abundance and night hourly dispersal of the vesicating beetles of the genus Paederus (Coleoptera: Staphylinidae) attracted to fluorescent, incandescent, and black light sources in the Brazilian savanna. J Med Entomol. 2015, 52:50-55.

10.1093/jme/tju006 